\title{
Cooperatif Learning Model to Reduce Mathematics Anxiety in High School Physics Learning
}

\author{
Ellianawati $^{1}$, Supriyadi ${ }^{2}$, N. Istikomah ${ }^{3}$ \\ Physics Departement, Universitas Negeri Semarang, Indonesia \\ Corresponding email: ellianawati@mail.unnes.ac.id
}

\begin{abstract}
Physics is one field of study that requires adequate mathematical skills in analyzing and solving problems in physics. However, based on research reports, there are still many high school students who experience anviety in solving mathematical problems which are called mathematical anxiety. This research is a descriptive analysis study to formulate a theoretical model of cooperative learning that is suitable for reducing mathematics anxiety by comparing the model of Teams Games Tournament (TGT), Team Assisted Individualization (TAI), and Think Pair Share (TPS). Strengths, weaknesses and opportunities for implementation are discussed.
\end{abstract}

Keywords: Mathematics Anxiety, Cooperative Learning, High School Physics

\section{Introduction}

Mathematics and physics have a close relationship where mathematical methods are widely used in physics and vice versa, concepts, opinions, and ways of thinking of physics are used in mathematics (Tzanakis, 2002). Mathematics greatly helps a person's reasoning process by tracing the intricacies of the concepts of physics (Wiladatika et al., 2017). Mathematics plays an important role in the learning of physics due to its ability to simplify the problem by formulating it into mathematical equations.

The results of the study by Rhahim \& Tandililing (2015) showed that the lower the mathematical skills of students, the less ability to solve physics problems. This is in accordance to what was stated by Anisa (2011) and Lukyto (2009) that mathematics contributes an important role in solving physical problems. It is indicate that adequate mathematical ability of students will greatly influence their high level of confidence in learning physics. Conversely, students with less mathematical abilities will tend to experience anxiety in studying physics. Student anxiety when dealing with mathematical problems is often referred to as mathematics anxiety.

Brody \& Rosenfield (2010) have mentioned the signs of students who experience mathematics anxiety including feeling of panic when taking any subject related to mathematics; experiencing paranoid thinking that everyone knows the answers of problems related to mathematics except himself; feel like a fool for years and everyone knows that; acting as if he could do nothing more to improve his achievements and not make any effort for that; and not believing in their own abilities. It appears that the main problem of mathematical anxiety is how to foster students' confidence in solving physical problems.

The situation described by Brody \& Rosenfield (2010) often leads to the attitude of students who rely more on memorizing formulas than understanding the concepts. Such circumstances often occur in high school and this is very influential on the poor mastery of the concept of physics. Therefore, it is important to design a learning process that can provide opportunities for students to reduce the mathematics anxiety they experience, thus helping their mastery of the concept of physics. One of learning model promises to meet the needs of students with mathematics anxiety is a cooperative learning model.

There are three cooperative learning models that are widely studied by researchers and are left to contribute significantly to improve students' confidence in solving problems. They are the model of Teams Games Tournament (TGT), Team Assisted Individualization (TAI), and Think Pair Share (TPS). However, it is necessary to study the most significant influence given by the three models in reducing students' mathematics anxiety. The finding is expected to provide a positive discourse for teachers and education practitioners who care about efforts to reduce students' math anxiety.

\section{Methods}

The method used in this study is quasiexperimental research. The three models were tested in three different classes with three types 
of sequences based on the learning topics in each class. The trial of this model was carried out in one of the high schools in Batang, Central Java with respondents from class $\mathrm{X}$. The topics studied were momentum and impulses based on observations that were the most difficult to master even though the phenomenon was close to students. To obtain data on its effectiveness, it was carried out by giving a standard test of mathematics anxiety that was modified for the physics context. This model test is presented in table 1 .

Table 1. Model Test Design

\begin{tabular}{lccc}
\hline & Class A & Class B & Class C \\
\hline Sub topics 1 & TGT & TAI & TPS \\
Sub topics 2 & TAI & TPS & TGT \\
Sub topics 3 & TPS & TGT & TAI \\
\hline
\end{tabular}

\section{Results and Discussion}

The implementation of the learning model trial conducted gives a significant influence on the reduction of students' mathematical anxiety as in Table 2.

Table 2. Mathematics Anxiety Score of Participants

\begin{tabular}{ccccc}
\hline \multirow{2}{*}{ Clas } & \multicolumn{2}{c}{ Initial } & \multicolumn{2}{c}{ Final } \\
\cline { 2 - 5 } $\mathrm{s}$ & Score & Categorie & Score & Categorie \\
& $\mathrm{s}$ & $\mathrm{s}$ & $\mathrm{s}$ & $\mathrm{s}$ \\
\hline $\mathrm{A}$ & 50.9 & high & 41.0 & moderate \\
$\mathrm{B}$ & 49.3 & moderate & 43.2 & moderate \\
$\mathrm{C}$ & 45.9 & moderate & 38.9 & low \\
\hline
\end{tabular}

Based on the data presented in Table 2 it appears that the three models have a strong tendency to reduce math anxiety. However, based on categories from the three classes, it is shown that Class $\mathrm{C}$ achieves the lowest mathematical anxiety score. To obtain the most effective data on mathematics anxiety reduction, data analysis was carried out based on gain score and obtained a description as presented in Figure 1 .

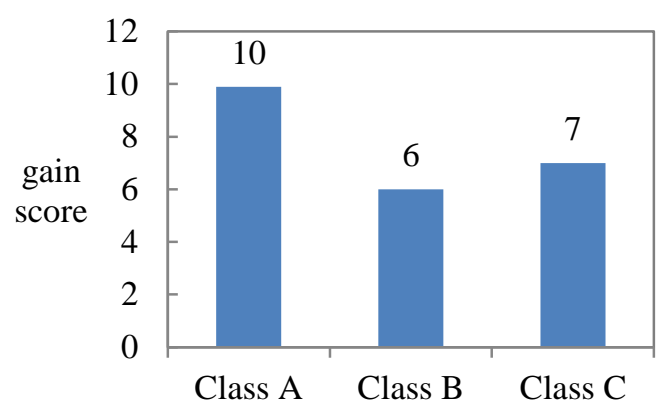

Figure 1. Gain score of mathematics anxiety reduction

Data Figure 1 clarifies the contribution of the implementation of the implementation of the three models that in Class A have the most significant influence. The TGT model with the characteristics of involving students in the game and the atmosphere of joy (Purnamasari , 2013) turned out to be able to reduce students' anxiety in learning. The TAI model that puts students ready to solve problems through group work (Widodo, 2015) helps gradually reduce their mathematical anxiety. TPS model that provides psychological therapy to discuss and process information (Yulianti et al., 2012) can bring a structured and conducive learning atmosphere.

These results indicate that the cooperative learning model through collaboration with learning systems with peers (Subali et al., 2012) will give a positive influence on student learning outcomes because of the teacher.

This combination will certainly have a different effect on different respondents. However, overall all three combinations show a significant reduction in mathematical anxiety towards students. Mathematics as an important part in human life should be well imbued by the students, both in social interactions in everyday life and as a language and tool in the development of science and technology.

Almost all fields of study require mathematics in their scientific studies as a powerful, concise, and clear means of communication; as a tool to present information in various ways; as a means to improve the ability to think logically, thoroughly, and space awareness; as well as giving satisfaction to the effort in solving challenging problems (Indiyani \& Listiara, 2006).

The results of research conducted by Sakarti \& Mirza's (2016) and Auliya (2013) revealed that there is a negative linear relationship between anxiety and the ability to solve mathematical problems. Therefore, the 
lack of mathematical skills is one of the factors that influence the low learning outcomes of physics.

It is needed a learning that is in accordance with students' learning styles (Ellianawati \& Wahyuni, 2010) in order to obtain optimal learning outcomes including in terms of reducing math anxiety and based on this research data the cooperative model has made a real contribution.

\section{Conclusion}

Based on the discussion, it can be concluded that the combination of cooperative learning model tested in high school physics learning is significantly reduce the mathematics anxiety of students. Each sequence of the combinations give the different effect on reduction of mathematics anxiety.

\section{References}

Anisa, A. 2011. Hubungan Kemampuan Logika Matematika dan Minat Belajar dengan Hasil Belajar Fisika. Skripsi. Surakarta: Universitas Sebelas Maret.

Auliya, R. N. 2013. Pengaruh Model Cooperative learning Tipe CRH (Course, Review, Hurray) terhadap Kemampuan Pemahaman Matematis dan Kecemasan Matematika Siswa SMP. Skripsi. Bandung: Universitas Pendidikan Indonesia.

Brody, J. \& R. Steve. 2010. Problem Posing/Solving and Linear Algebra. International Journal of Mathematical Education in Science and Technology, 27(1): 103-121.

Ellianawati \& S. Wahyuni. 2010. Pemanfaatan Model Self Regulated Learning sebagai Upaya Peningkatan Kemampuan Belajar Mandiri pada Mata Kuliah Optik. Jurnal Pendidikan Fisika Indonesia, 6: 35-39.

Indiyani, N. E. \& A. Listiara. 2006. Efektivitas Metode Pembelajaran Gotong Royong (Cooperative Learning) untuk Menurunkan Kecemasan Siswa dalam Menghadapi Pelajaran Matematika. Jurnal Psikologi
Universitas Diponegoro, 3(1): 10-28.

Lukyto, T. 2009. Hubungan antara Kemampuan Dasar Matematika dan Kebiasaan Belajar Siswa dengan Prestasi Belajar Fisika pada Bab Cahaya Siswa SMP Negeri 3 Ponorogo. Skripsi. Malang: Universitas Negeri Malang.

Purnamasari, Y. 2013. Pengaruh Model Cooperative learning Tipe Team Games Tournaments (TGT) terhadap Kemandirian Belajar dan Peningkatan Kemampuan Penalaran dan Koneksi Matematik Peserta Didik SMPN 1 Kota Tasikmalaya. Tesis. Universitas Terbuka.

Rhahim, E. \& E. Tandililing. 2015. Hubungan Keterampilan Matematika dengan Kemampuan Menyelesaikan Soal Fisika terhadap Miskonsepsi Siswa pada Impuls Momentum. Jurnal Pendidikan dan Pembelajaran, 4(9).

Sakarti, H. \& A. Mirza. 2016. Hubungan Kecemasan dan Kemampuan Siswa dalam Menyelesaikan Masalah Matematika. Jurnal Pendidikan dan Pembelajaran, 5(12): 1-12.

Subali, B. A. Sopyan, \& R. Munawaroh. 2012 Penerapan Model Project BAsed Learning dan Kooperatif untuk Membangun Empat Pilar Pembelajaran Siswa SMP. Unnes Physics Education Journal, 1(1): 33-37.

Tzanakis, C. 2002. On The Relation Between Mathematics and Physics in Undergraduate Teaching. 2nd International Conference on the Teaching of Mathematics (at the undergraduate level): 387 .

Wiladatika, L., S.S. Sitompul, \& D. Mahmuda. 2017. Hubungan Keterampilan Matematika dengan Kemampuan Menyelesaikan Soal Materi Gaya pada Siswa SMP Mujahidin Pontianak. Jurnal Pendidikan dan Pembelajaran, 6(1): 1-9.

Yulianti, D., H. Susanto, \& E. Nurnawati. 2012. Peningkatan Kerjasama Siswa SMP melalui Penerapan Pembelajaran Kooperatif Pendekatan Think Pair Share. Unnes Physics Educational Journal, 1(1): 1-7. 